\title{
Do patients benefit from platelet-rich plasma?
}

\author{
O. Şahap Atik, MD D \\ Professor of Orthopedic Surgery, Turkish Joint Diseases Foundation, Ankara, Turkey
}

Orthobiologics are biologically derived materials which aim to promote regeneration of tissues that are the focus of orthopedic surgery. ${ }^{[1]}$ Platelet-rich plasma (PRP) is derived from patients' complete blood and then centrifuged with various techniques to acquire growth factors such as platelet-derived growth factor, transforming growth factor- $\beta 1$, epidermal growth factor, fibroblast growth factor, and others.

Patellar tendon seems to benefit from PRP injections, while there is no proven benefit for Achilles tendon, rotator cuff pathology, or lateral elbow tendinopathy. ${ }^{[2]}$

Platelet-rich plasma could be a promising bioactive scaffold for the delivery of chondroprogenitors in cartilage healing due to its synergistic effect in supporting cell proliferation, maintaining cell viability, and favoring extracellular matrix production. ${ }^{[3]}$

The addition of PRP to a poly lactic-co-glycolic acid (PLGA) scaffold with continuous passive

Received: August 04, 2020

Accepted: August 13, 2020

Published online: September 11, 2020

Correspondence: O. Şahap Atik, MD. Turkish Joint Diseases

Foundation, Mustafa Kemal Mah., Dumlupınar Bul., 274/2

C2 Blok, Ofis 5, 06900 Çankaya, Ankara, Türkiye.

E-mail: satikmd@gmail.com

Doi: 10.5606/ehc.2020.57895

Citation: Atik OŞ. Do patients benefit from platelet-rich plasma? Jt Dis Relat Surg 2020;31(3):409-410.

O2020 All right reserved by the Turkish Joint Diseases Foundation

This is an open access article under the terms of the Creative Commons Attribution-NonCommercial License, which permits use, distribution and reproduction in any medium, provided the original work is properly cited and is not used for commercial purposes (http://creativecommons.org/licenses/by-nc/4.0/). motion in osteochondral defects may be beneficial for hyaline cartilage and subchondral bone tissue repair. However, PRP alone (with or without PLGA implants) is limited to osteochondral defect repair without significant regeneration. ${ }^{[4]}$

A synergistic effect of hyperbaric oxygen (HBO) and PRP on knee cartilage may result in better regeneration. ${ }^{[5]}$ Although the details are not well understood, the aggregation and activation of growth factors released from platelets whose activation is increased in the hyperbaric environment may explain this synergistic effect. This may result in better regeneration than the effect of PRP or HBO alone.

The possible effects of leukocyte concentration in the content of PRP and the administration of PRP using a drug delivery system on chondrocyte proliferation are searched in vitro conditions. Authors showed that leukocyte-rich PRP administered with a delivery system such as hydrogel is more efficient than conventional applications of PRP in the treatment of cartilage damage in vitro. ${ }^{[6]}$

However, the results of another study indicate that leukocyte-poor PRP may promote tendon healing through anabolic effects while leukocyterich PRP may impair the repair process. ${ }^{[7]}$

Current clinical experience on orthobiologics should be regarded as first steps for the new concept of musculoskeletal system healing and is still in experimental stage. ${ }^{[1]}$ No definitive conclusions can be established about the effects of PRP in such conditions since most studies are of low to moderate methodological quality and use variable PRP protocols. For these reasons, there is a growing debate regarding PRP's clinical efficacy. ${ }^{[8]}$

In conclusion, PRP is being marketed as a promising new product of regenerative medicine 
that is superior to other current therapies. However, unfortunately, it still lacks robust evidence to support its use in clinical practice. Orthopedic surgeons should be aware of the ongoing uncertainty about the evidence behind PRP therapies and inform patients about this fact.

\section{REFERENCES}

1. Sezgin EA, Atik OŞ. Are orthobiologics the next chapter in clinical orthopedics? A literature review. Eklem Hastalik Cerrahisi 2018;29:110-6.

2. Filardo G, Di Matteo B, Kon E, Merli G, Marcacci M. Platelet-rich plasma in tendon-related disorders: results and indications. Knee Surg Sports Traumatol Arthrosc 2018;26:1984-99.

3. Vinod E, Vinod Francis D, Manickam Amirtham S, Sathishkumar S, Boopalan PRJVC. Allogeneic platelet rich plasma serves as a scaffold for articular cartilage derived chondroprogenitors. Tissue Cell 2019;56:107-13.
4. Chang NJ, Erdenekhuyag Y, Chou PH, Chu CJ, Lin CC, Shie MY. Therapeutic effects of the addition of plateletrich plasma to bioimplants and early rehabilitation exercise on articular cartilage repair. Am J Sports Med 2018;46:2232-41.

5. Korucu İH, Kekeç AF, Arslan A, Oltulu P, Korucu EN, Özer $M$. Regenerative effects of hyperbaric oxygen therapy and platelet-rich plasma on the osteochondral defects of rats. Jt Dis Relat Surg 2020;31:260-6.

6. Yaşar Şirin D, Yılmaz İ, İsyar M, Öznam K, Mahiroğulları M. Does leukocyte-poor or leukocyte-rich platelet-rich plasma applied with biopolymers have superiority to conventional platelet-rich plasma applications on chondrocyte proliferation? Eklem Hastalik Cerrahisi 2017;28:142-51.

7. Yan R, Gu Y, Ran J, Hu Y, Zheng Z, Zeng M, et al. Intratendon delivery of leukocyte-poor platelet-rich plasma improves healing compared with leukocyte-rich platelet-rich plasma in a rabbit achilles tendinopathy model. Am J Sports Med 2017;45:1909-20.

8. Atik OŞ. Every new technique either conservative or surgical is good? Eklem Hastalik Cerrahisi 2019;30:183-4. 